PRZEGLĄD NAUK HISTORYCZNYCH 2016, R. XV, NR 1

http://dx.doi.org/10.18778/1644-857X.15.01.06

DROBNE PRACE I MATERIAEY

IRENEUSZ MiLewsKi

(Uniwersytet GDAŃsKi)*

\title{
Panegyris. Kilka uwag o ludycznych i ekonomicznych aspektach świąt męczenników w okresie wczesnobizantyńskim ${ }^{1}$
}

\footnotetext{
J
}

ednym $z$ wielu aspektów chrystianizacji imperium rzymskiego było popularyzowanie kultu męczenników, chociażby przez organizowanie świąt $\mathrm{ku}$ ich $\mathrm{czci}^{2}$. Wydarzenia te masowo przyciagały okolicznych pielgrzymów ${ }^{3}$, a nierzadko również pątników $z$ sąsiednich prowincji ${ }^{4}$. Poza czynnikiem religijnym, wynikającym w dużej mierze $z$ ludowego postrzegania korzyści płynących $z$ obecności w pobliżu relikwii męczennika w dniu jego święta ${ }^{5}$, tłumy

* Wydział Historyczny, Instytut Historii, Zakład Historii Starożytnej.

1 Artykuł powstał w ramach prac nad projektem finansowanym ze środków Narodowego Centrum Nauki na podstawie decyzji nr: UMO-2011/01/B/HS3/01233.

2 J. B e rn ar di, La prédication des Pères Cappadociens, Montpellier 1968, s. 85; L. Grig, Making Martyrs in Late Antiquity, London 2004, s. 25.

3 Joannes Chrysostomus, De sanctis martyribus, "Patrologia Graeca" [Paris] 1862, t. XLIX, col. 647; Basiliu s Magnus, In Gordium martyrem, „Patrologia Greaca" [Paris] 1857, t. XXXI, col. 489. W tej kwestii por. także M. Gir ardi, Basilio di Cesarea e il culto dei martyri nel IV secolo. Scrittura et tradizione, Bari 1990, s. 71; K. Har1, From Pagan to Christian in Cities of Roman Anatolia during the Fourth and Fifth Centuries, [w:] Urban Centers and Rural Contexts in Late Antiquity, eds Th.S. Burns, J.W. Eadie, East Lansing 2001, s. 308.

${ }^{4}$ M.W. Graham, News and Frontier Consciousness in the Late Roman Empire, Michigan 2009, s. 113.

${ }^{5}$ Akcentowane, co ciekawe - nie w ówczesnych kościelnych tekstach normatywnych, lecz przez kaznodziejów, przekonanie, a w zasadzie wiara w szczególna moc relikwii świętego w dniu jego święta, por. Gregorius Nys s enus, De sancto Theodoro martyre, "Patrologia Graeca” [Paris] 1863, t. XLVI, col. 745; J oa n nes Chrysos tomus, De sancto Babyla, contra Julianum et gentiles 12, „Patrologia Graeca" [Paris] 1862, t. L, col. 551-552; Theodoretus Cyrensis, Graecarum 
pielgrzymów przyciagał organizowany przy tej okazji jarmark, w chrześcijańskich tekstach greckich określany terminem panegyris. W tych samych tekstach terminem panegyris określa się również święta organizowane ku czci męczenników. Ta zbieżność nie jest przypadkowa. W kręgu kultury greckiej jarmark (panegyris) był nieodłącznym elementem świąt organizowanych ku czci bogów $\mathrm{i}$ herosów ${ }^{6}$. Termin panegyris jest terminem opisowym, a w interesującym nas kontekście oznacza grupe ludzi, która w konkretnym celu zebrała się w pewnym miejscu ${ }^{7}$. Panegyris organizowany chociażby w Olimpii, w czasie święta ku czci Zeusa, trwał aż trzy dni ${ }^{8}$. Na dorocznym jarmarku można było zakupić drobne dewocjonalia potwierdzające odbycie pielgrzymki oraz skorzystać $z$ ofert stoisk gastronomicznych. Można było również przeprowadzić transakcje handlowe zakrojone na wielka skalę ${ }^{9}$. Co oczywiste, zarówno w tradycji pogańskiej, jak i chrześcijańskiej sasiedztwo świątyń, sanktuariów herosów czy też kaplic chrześcijańskich męczenników

affectione curratio VIII, 11, „Patrologia Graeca” [Paris] 1864, t. LXXXIII, col. 1011 B, tłum. S. Kalinkowski, [w:] T e o d or et z Cy ru, Leczenie chorób hellenizmu, Warszawa 1981, s. 173. Więcej w tej kwestii por. P.M. B e go n, The Cappadocian Fathers, Women and Ecclesiastical Politics, „Vigiliae Christianae” 1995, vol. XLIX, s. 167; A. Papaconstantin ou, The Cult of Saints: A Haven of Continuity in a Changing World, [w:] Egypt in the Byzantine World, 300-700, ed. R.S. Bagnall, Cambridge 2007, s. 355.

${ }^{6}$ L. de Light, Fairs and Markets in the Roman Empire. Economic and Social Aspects of Periodic Trade in a Pre-Industrial Society, Amsterdam 1993, s. 35-39, 56-105, 64 i n., 70 n.; R. Bagnall, Egypt in Late Antiquity, Princeton 1993, s. 101-105; D. Frankfurter, Religion in Roman Egypt. Assimilation and Resistance, Princeton 1998, s. 58-62; S.R.F. Pric e, Rituals and Power. The Roman Imperial Cult in Asia Minor, Cambridge 2002, s. 101-132; A. Harland, Travel and Religion in Antiquity, Waterloo 2011, s. 6; M.P. Nills o n, Greek Folk Religion, New York 1998, s. 97.

${ }^{7}$ L. Ziehen, Panegyris, „Real - Encyclopädie der classischen Altertumswissenschaften" 1983, Jg. XVIII, Tl. 3, s. 581.

${ }^{8}$ F. S peck, Handelsgeschichte des Altertums, Bd. II (Die Griechen), Paderborn 1901, s. 424; E.O. J a me s, Seasonal Feast and Festivals, New York 1961, s. 155; L. Ziehen, op. cit., s. 582; O.M. van Nijf, The Civic World of Professional Associations in the Roman East, Leiden 1997, s. 141.

${ }^{9}$ E.O. James, op. cit., s. 134; L. de Ligt, P.W. de Neeve, Ancient Periodic Markets: Festivals and Fairs, „Athanaeum” 1988, vol. LXXV, s. 397; H. Hellenkamper, F. Hild, Lykien und Pamphylien, [w:] Tabula Imperi Byzantini 6, Wien 2004, s. 184; J. Leemans, Individualization and the Cult of the Martyrs: Examples from Asia Minor in the Fourth Century, [w:] The Individual in the Religions of the Ancient Mediterranean, ed. J. Rüpke, Oxford 2013, s. 202; N. Morley, The Market in Classical Antiquity, [w:] M. Fras s, Kauf und Märkte. Wirtschaftsleben im Focus. Vom der römischen Antike bis zur Gegenwart, Wiesbaden 2013, s. 112-114. 
także poza okresem świąt było przestrzenią, w której prowadzono handel dewocjonaliami, chociażby figurkami czczonych tam bóstw (żeby przypomnieć opisywany w Dziejach Apostolskich przypadek efeskich sprzedawców figurek bogini Afrodyty ${ }^{10}$ ) bądź też ampułkami zawierającymi „cudowną” wodę lub oliwę, stosowaną w celach leczniczych, opatrzonymi wizerunkiem świętego męża, co miało propagować jego kult, ale też chronić pielgrzyma w jego drodze powrotnej ${ }^{11}$. Opisane poniżej zjawisko, jarmarku corocznie organizowanego $z$ okazji świąt ku czci męczenników, wyrosło $z$ wielowiekowej tradycji, która - jak się przypuszcza - do kręgu kultury greckiej przeniknęła $z$ Egiptu ${ }^{12}$.

Atmosferę panująca w czasie panegyris towarzyszącemu bliżej nieokreślonemu świętu religijnemu świetnie oddaje krótka relacja Diona Chrysostoma (40-120). W jednej z jego mów czytamy: „Na panegyris kupcy przywożą towary wszelkiego rodzaju, rzemieślnicy swe wyroby, inni wykorzystuja okazje, by zaprezentować własne umiejętności, deklamując poezje, tragedię albo też dzieła pisane prozą"13.

Co oczywiste, pogańskie święta religijne połączone $z$ jarmarkiem (panegyris) nadal organizowane były u schyłku antyku. Relacji na ich temat mamy co prawda niewiele, tym bardziej godna jest odnotowania informacja, jaka o nich odnajdujemy w Konstytucjach Apostolskich. Ich autor, przestrzegajacc chrześcijan przed praktykowaniem antycznej magii, oionomantei, nekromantei oraz innych technik dywinacyjnych, ostrzega ich także przed braniem

10 Dzieje Apostolskie 19, 11-14.

${ }^{11}$ G. Vika n, "Guided by Land and Sea”. Pilgrim Art and Pilgrim Travel in Early Byzantium, [w:] Tesserae: Festschrift für Josef Engemann, „Jahrbuch für Antike und Christentum. Ergänzungsband" 1991, Jg. XVIII, s. 79-81; J. Engemann, Palästinische frühchristliche Pilgerampullen. Erstveröffentlichungen und Berichtigungen, „Jahrbuch für Antike und Christentum” 2002, Jg. XLV, s. 158-160; I. Milewski, Kilka uwag o paramedycznym zastosowaniu oliwy przez chrześcijan w okresie wczesnobizantyńskim, „Vox Patrum” 2014, R. LXII, s. 357-364. Por. wyniki prac archeologicznych prowadzonych przez niemieckiego archeologa C.M. Kaufmanna w Abu Mena, mieście św. Menasa. Na badanym obszarze, w pobliżu sanktuarium, odnalazł on pozostałości po warsztatach. Produkowano w nich wspomniane ampułki oraz lampki oliwne opatrzone wytłaczanym lub namalowanym wizerunkiem świętego męża, por. C.M. Kaufmann, Die heilige Stadt der Wüste, Kempten 1924, s. 194.

${ }^{12}$ L. Ziehen, op. cit., s. 582.

${ }^{13}$ Dio Chrysostom, Oratio XXVII, 5, [w:] idem, Discources 12-30, ed. J.W. Cohoon, Cambridge-London 1939. 
udziału w świętach pogan, których - jak autor relacji stwierdza - nierozłącznym elementem był panegyris oraz „Związane $z$ nim rozrywki” ${ }^{14}$.

Krytykowane jeszcze w Kanonach Apostolskich (powstałych, w zachowanej do naszych czasów wersji, w kręgu syryjskim u schyłku IV w.) jarmarki organizowane przez pogan już w drugiej połowie IV w. były nieodłacznym elementem świąt ku czci męczenników na terenie Kapadocji. Nadal jednak były krytykowane w pismach ówczesnych autorów chrześcijańskich za panującą tam atmosferę. Święta ku czci męczenników, trwające nierzadko nawet tydzień ${ }^{15}$, organizowano w rocznicę ich śmierci, choć nie zawsze była ona znana. W takim przypadku moment translacji relikwii uznawany był za świętą datę ${ }^{16}$. U schyłku starożytności w niektórych Kościołach za kłopotliwe w tej mierze uchodziły również inne przypadki: kiedy rocznica śmierci męczennika przypadała na okres postu. Jedyna znana nam w tej mierze regulacja ogłoszona u schyłku IV w. we Frygii dopuszczała obchodzenie święta męczennika przypadającego na okres Wielkiego Postu tylko w dwa dni w tygodniu, mianowicie w sobotę i w niedzielę ${ }^{17}$. Powyższy kanon, uchwalony na niewielkim synodzie lokalnym, nie był zapewne wiążący dla innych Kościołów na Wschodzie, nie mówiąc o biskupstwach w zachodnich prowincjach Cesarstwa.

Jarmark stwarzał więc możliwość uczestniczenia w wielkim wydarzeniu handlowym, nierzadko o skali ponadprowincjonalnej. Stanowił dodatkowy bodziec dla pielgrzymów licznie odwiedzających kaplice męczenników $z$ reguły w wigilię ich święta ${ }^{18}$. Tak jak zostało

${ }^{14}$ Konstytucje Apostolskie II, 62, 4, tłum. S. Kalinkowski, [w:] Konstytucje apostolskie oraz Kanony Pamfilosa $z$ apostolskiego synodu $w$ Antiochii. Prawo kanoniczne św. Apostołów. Kary świętych Apostołów dla upadłych. Euchologion Serapiona, [w:] Synody i kolekcje praw (= Synodi et Collectiones Legum), t. II, wyd. A. Baron, H. Pietras, Kraków 2007, s. 77-78.

${ }^{15}$ V. Karras, Life of St. Elisabeth the Wonderworker, [w:] A.M. Talbot, Holy Women of Byzantium. Ten Saints'Lives in English Translation, Washington 2006, s. 123. Święta pogańskich bogów potrafiły trwać nierzadko nawet miesiąc, por. B. Kötting, Peregrinatio religiosa. Wallfahrten in der Antike und das Pilgerwesen in der alten Kirche, Münster 1980, s. 52.

16 J. Leemans, op. cit., s. 201.

17 Por. kanon 51 synodu w Laodycei: „W czasie Wielkiego Postu nie należy obchodzić narodzin męczenników, można je wspominać jedynie w soboty i w niedziele", tłum. S. Kalinkowski, [w:] Acta Synodalia, t. IV, wyd. A. Baron, H. Pietras, Kraków 2010, s. 118.

${ }_{18}$ S. Vryonis, The Panegyris of the Byzantine Saint: A Study in the Nature of a Medieval Institution, its Origin and Fate, [w:] The Byzantine Saint, ed. S. Hackel, London 1981, s. 196; A.M. Orse1li, L'idée chrétienne de la ville: quelques 
to zasygnalizowane, w opisach przebiegu świąt ku czci męczenników organizowanych u schyłku antyku dostrzegamy analogię ze świętami ku czci pogańskich bogów i herosów, wydarzeń których nieodłącznym elementem był jarmark. Chrześcijańscy męczennicy, niczym antyczni herosi, swa postawa wobec prześladowców oraz męczeńska śmiercią $\mathrm{w}$ obronie wiary mieli być wzorem dla wiernych w ich codziennych zmaganiach. W przypadku herosów zaś na naśladowanie zasługiwało przede wszystkim ich męstwo oraz poświęcenie w imię spraw wyższych, dla dobra innego człowieka. Herosi, podobnie jak chrześcijańscy męczennicy, mieli swe kaplice, a nierzadko również okazałe sanktuaria $z$ oczywistych względów usytuowane w pobliżu ośrodków miejskich, do których szczególnie licznie przybywano w dniu ich święta. Także w tym przypadku wierzono, że właśnie wtedy można nawiązać $z$ nimi szczególny kontakt. Herosi zaś, doceniając trud przybyłych pątników, łaskawszym okiem spoglądali na ich prośby, przyczyniając się do uzdrowienia ich $z$ różnorakich chorób, wypędzenia demona czy też patronując konkretnemu życiowemu przedsięwzięciu. Czyż w takim postrzeganiu „mocy” antycznego herosa nie dostrzegamy pierwowzoru przesłanek, jakimi kierowali się chrześcijańscy pielgrzymi przybywający do martyrionów w dniu święta męczennika? ${ }^{19}$

Panegyris stał się więc nieodłacznym elementem organizowanych świąt ku czci męczenników. Autorzy chrześcijańscy ubolewali nad tym, że $z$ powodu wielkiej popularności owych jarmarków religijny aspekt świąt schodził na dalszy plan, przez co też bardziej przypominały one ludowe festyny. Co oczywiste, organizowanie $\mathrm{w}$ tym dniu jarmarku nie wypływało $z$ religijnego charakteru święta. Przede wszystkim było skutkiem nagromadzenia się większej liczby pielgrzymów, choć istniała w tej mierze także pewna zależność. Organizowanie jarmarku w czasie święta było zapewne dodatkowym magnesem liczniej przyciagającym pielgrzymów. Pośpiesznie budowano więc stragany oraz stoiska gastronomiczne. To zaplecze handlowe gwarantowało peregrynantom nie tylko zaspokojenie głodu i pragnienia, lecz także zakupienia pewnych towarów, również różnego rodzaju dewocjonaliów potwierdzających odbycie pielgrzymki.

suggestions pour l'Antiquité Tardive et le haut Moyen Age, [w:] The Idea and Ideal of the Town between Late Antiquity and the Early Middle Ages, eds G.P. Brogiolo, B. Ward-Perkins, Leiden-Boston-Köln 1999, s. 187.

${ }^{19}$ L. Ziehen, op. cit., s. 581; J. Menirav, B.Z. Rosenfeld, Markets and Marketing in Roman Palestine, Leiden 2005, s. 33-38, 50-58. 
Omówione poniżej zjawisko rekonstruujemy przede wszystkim na podstawie relacji późnoantycznych autorów chrześcijańskich, choć równie ważnym źródłem poznania form ówczesnego kultu świętych, odbywanych wówczas pielgrzymek sa licznie zachowane do naszych czasów pielgrzymie ampułki ${ }^{20}$. Ich geograficzny zasięg potwierdza popularność kultu konkretnego męczennika czy też świętego męża w odległych zakątkach imperium rzymskiego.

Przejdźmy jednak do omówienia konkretnych relacji. Niestety są one nieliczne, a do tego jeszcze nie zawsze w precyzyjny sposób nawiązuja do interesującej nas kwestii. Kilka $z$ nich wyszło spod pióra Bazylego Wielkiego. W homilii wygłoszonej w czasie święta Mamantasa stwierdza, że chęć uczestniczenia w festynie ku czci męczennika była tak silnym magnesem, iż zarzucano wszelkie obowiązki, rzekomo wcześniej niecierpiące zwłoki, okolica martyrionu zaś w dzień święta zmieniała się w wielki plac targowy ${ }^{21}$.

Do nastrojów nielicujących $z$ powaga uroczystości, panujących między pielgrzymami przybyłymi na święto męczenników, nawiązuje Bazyli również w jednej ze swych Regut. Z relacji tej wynika, $\dot{z}$ e to nierzadko doczesne korzyści bardziej przyciagały pielgrzymów do kaplic męczenników niż chęć uczestniczenia w uroczystościach religijnych. W relacji Bazylego czytamy: „By przebywać w miejscach spoczynku męczenników lub w pobliżu tych miejsc, chrześcijanie nie moga mieć innych motywów, jak tylko pragnienie oddania się modlitwie $z$ taką samą gorliwością, $z$ jaka ci święci wytrwali w miłości do Boga aż po śmierć. Należy pamiętać o straszliwym gniewie Pana: On, który był zawsze i wszędzie cichy i pokornego serca, jak jest napisane, podniósł bicz jedynie na tych, którzy sprzedawali i kupowali w świątyni, ponieważ prowadzenie handlu zamieniło dom modlitwy w jaskinię zbójców. A jednak inni doprowadzili do porzucenia zwyczaju przestrzeganego w stosunku do świątyń. Zamiast modlić się jedni za drugich, korzyć się razem i płakać przed Bogiem błagając Go o litość za swoje grzechy, zamiast składać dziękczynienia i być dla siebie przykładem przez pobożne rozmowy, co widzieliśmy dawniej, korzystaja z miejsca i sposobności, aby zajmować się handlem, organizować jarmarki i odbywać targi publiczne (...kai panegyrin). Ale właśnie nie w tym

${ }^{20}$ G. Vikan, op. cit., s. 79-81; J. Engemann, op. cit., s. 158-160.

${ }^{21}$ Basilius Magnus, In Mamantem homilia 2, „Patrologia Graeca” [Paris] 1857, t. XXXI, col. 592. 
mamy iść za ich przykładem i potwierdzać tę niestosowność przez swoje uczestnictwo"22.

Do - jak się wydaje - równolegle organizowanego ze świętem męczennika jarmarku nawiąuje również w jednej ze swych homilii Grzegorz z Nyssy. Zwraca on uwage, że przybyli przy tej okazji do miasta pątnicy są bardziej podekscytowani możliwością uczestniczenia w jarmarku i możliwością dobicia korzystnego targu niż przeżywaniem uroczystości religijnej. W opisywanym przypadku harmider panujący w kościele w czasie wygłaszania kazania był tak wielki, że biskup postanowił przerwać kazanie ${ }^{23}$.

Jarmark organizowany $\mathrm{w}$ pobliżu martyrionu $\mathrm{w}$ dniu święta męczennika przyciągał również ludzi marginesu ${ }^{24}$. Ten fakt odnotowuje w jednej ze swych relacji Szenute z Atrypy. Wynika $z$ niej, że owe święta swym charakterem bardziej przypominały najgorszego sortu ludowe festyny ze wszechobecnymi złodziejami, prostytutkami nachalnie oferujacymi swe usługi, plotkujacymi, rozbawionymi i nietrzeźwymi pątnikami, między którymi nieraz dochodziło do bójki. Kiedy w czasie uroczystości religijnych śpiewano w kościele psalmy, z miejsca, w którym odbywa się jarmark, dochodziły dźwięki cymbałów i fletów, słowem: frywolna muzyka, nie tylko zagłuszająca uroczystości religijne w martyrionie, lecz przede wszystkim nielicujacca $z$ ich powaga. Masowo też odbywał się handel: jedni sprzedawali miód, inni bydło. Poza ludźmi marginesu, złodziejami i prostytutkami obiektem ataku egipskiego archimandryty sa niestosownie ubrane, umalowane i wyperfumowane chrześcijanki, które - jak wynika $z$ dalszej relacji Szenutego - przybyły na święto nie po to, by uczcić pamięć męczennika, lecz by ulec swym żądzom w którymś $z$ kościelnych zakamarków lub też przy jednym $z$ grobowców $^{25}$. Ta ostatnia informacja sugeruje, że martyrion, o którym

${ }^{22}$ I d e m, Regulae fusius tractatus 40, „Patrologia Graeca” [Paris] 1857, t. XXXI, col. 1020; tłum. J. Naumowicz, [w:] Św. Bazyli Wielki, Pisma Ascetyczne, t. II, Kraków 1995, Źródła monastyczne, t. VI, s. 153-154.

${ }^{23}$ Gregorius Nys senus, Oratio prima in quadraginta martyres, „Patrologia Graeca" [Paris] 1863, t. XLVI, col. 749.

${ }^{24}$ F. S peck, op. cit., s. 424.

25 J. Le i pold t, Schenute von Atripe und die Entstehung des national-ägyptischen Christentum, Leipzig 1903, s. 30. Por. też Paulinus Nolanu s, Carmen XX, „Patrologia Latina" [Paris] 1862, t. LXI, col. 521, który kpiąc z chrześcijan niedostatecznie przeżywających religijny aspekt święta, stwierdza, że okoliczni chłopi przybywaja do Noli na święto miejscowego męczennika Felixa ze swymi utuczonymi wieprzami oczywiście w zamiarze ich sprzedaży na równolegle odbywającym się jarmarku. 
wspomina w swej relacji egipski archimandryta, usytuowany był poza skupiskiem ludzkim, na miejscowym koimeterionie.

Analogiczna, choć już nie tak bogata w detale relacja wyszła również spod pióra Bazylego $z$ Seleucji. Opisuje on przebieg święta ku czci św. Tekli, legendarnej świętej z czasów św. Pawła Apostoła. Trwające kilka dni święto ku jej czci miało bardziej charakter ludowego festynu, pełnego zabaw i śpiewów, biegajacych dzieci, rozbawionych pątników krążących między stoiskami, na których można było kupić napitek i strawę. No i oczywiście zewsząd dobiegająca muzyka i tańce. Przy tej okazji Bazyli krytykuje kobiety, podrygujace $\mathrm{w}$ rytm muzyki młode chrześcijanki ${ }^{26}$. O panegyreis towarzyszących organizowanym w palestyńskiej Gazie świętom ku czci św. Sergiusza i Stefana krótko wspomina także Chorycjusz ${ }^{27}$.

Czy przytoczoną relację Szenutego z Atrypy o rozwiąłości pątników przybywających na jarmark towarzyszący świętom męczenników uznać należy za przesadzoną? Raczej nie. Pośrednio potwierdza to także Teodoret z Cyru. Opisując w swych Dziejach miłości Bożej (Historia religiosa) koleje żywota Marisa, jednego $z$ syryjskich mnichów, stwierdza, że jego bohater nie uległ żadnym żądzom mimo uczestniczenia w młodzieńczym wieku w wielu jarmarkach. W interesującej nas relacji czytamy: „Również wcześniejsze lata jego życia upłynęły na zmaganiach $z$ trudami, jakich wymaga cnota, i dzięki temu zachował czystość ciała i duszy. Sam mi wyjawił, że jego ciało pozostało czyste, takie, jakie wyszło $z$ matczynego łona. Jako młody człowiek w czasie obchodów licznych świąt ku czci męczenników (...kai tauta pollas men martyron panegyreis epitelesas) urzekał tłumy brzmieniem swego głosu - długi czas bowiem, kiedy błyszczał urokiem młodości, śpiewał psalmy - lecz ani piękno fizyczne, ani obcowanie z ludźmi nie splamiło piękności jego duszy"28.

Teodoret porusza tu ważna kwestię, która potwierdza nasze przekonanie o kontynuowaniu pogańskich wzorców utrzymujących się $\mathrm{w}$ trakcie panegyreis organizowanych przy okazji świąt ku czci

${ }^{26}$ Basilius Seleucien s is, De vita Theclae 19, „Patrologia Graeca”[Paris] 1864, t. LXXXV, col. 600. Wśród produktów, jakie można zakupić na jarmarku, Bazyli wymienia także mydło, por. ibidem 28, „Patrologia Graeca” [Paris] 1864, t. LXXXV, col. 613.

${ }^{27}$ F.K. Litsas, Choricius of Gaza and his Description of Festivals at Gaza, „Jahrbuch der Österreichischen Byzantinistik” 1982, Jg. XXXII, s. 427-436.

28 Theodoretus Cyrensis, Historia religiosa XX, „Patrologia Graeca” [Paris] 1864, t. LXXXII, col. 1429; tłum. K. Augustyniak, [w:] Te odoret z Cyru, Dzieje miłości Bożej. Historia mnichów syryjskich, Kraków 1994, Źródła monastyczne, t. VII, s. 221. 
męczenników. Elementem antycznego jarmarku były bowiem również konkursy poezji oraz hymnów religijnych recytowanych bądź śpiewanych $z$ okazji święta lub też w celu uczczenia osoby panującej (króla, cesarza, a czasami tylko namiestnika prowincji) ${ }^{29}$. To m.in. w czasie występów na panegyris organizowanemu w czasie jednego ze świąt Zeusa w Olimpii sławę sprawnego mówcy zyskał ateński retor Izokrates ${ }^{30}$. Wniosek, jaki można by wysnuć, analizując przekaz Teodoreta, jest taki, że by nadać jarmarkom organizowanym w czasie świąt męczenników bardziej chrześcijański charakter, by choćby w części odróżniały się one od analogicznych imprez pogańskich, organizowano przy tej okazji konkursy śpiewania psalmów i hymnów, religijnych pieśni, które $z$ przestrzeni codziennej chrześcijanina miały wyprzeć dawną, pogańską muzykę i śpiew jako, nawet w najprostszej formie, ostoję antycznej religii.

Teodoret $z$ Cyru, broniąc jednak kultu męczenników chrześcijańskich przed atakami środowisk pogańskich dopatrujacych się w nim kontynuacji antycznego kultu zmarłych, wychwala i idealizuje przebieg tych świąt, stwierdzając: „Pan umieścił swoich zmarłych na miejscu waszych bogów; przepędził bogów i męczennikom przyznał ich chwałę. Zamiast Pantadiów, Diazjów [attyckie święta ku czci Apollina i Zeusa - przyp. I.M.], Dionizjów i innych waszych świąt obchodzone sa [...] uroczystości na cześć Piotra, Pawła, Tomasza [...] i pozostałych męczenników; zamiast dawnych uroczystych procesji za sprośnymi gestami i słowami obchodzone sa pełne skromności święta, podczas których nie ma pijaństwa, hulanek i śmiechu; są tam (tylko) pobożne hymny, słuchanie świętych nauk i modlitwy okraszone chwalebnymi łzami"31.

Przytoczona relacja, swego rodzaju panegyrik na cześć kultu męczenników, to oczywiście wersja dla pogan, nie tylko krytykujących, ale wręcz naśmiewających się z kultu chrześcijańskich

${ }^{29}$ G. Kennedy, The Art of Persuasion in Greece, Princeton 1963, s. 166-167, 174-206; J.D. Garrison, Dryden and the Tradition of Panegryric, BerkeleyLos Angeles-London 1975, s. 7-8; F. Gasco, Menander Rhetor and the Works Attributed to Him, [w:] Aufstieg und Niedergang der Römischen Welt, Serie II, Bd. XXXIV, Tl. 4, Berlin-New York 1998, s. 3130; S. Vryonis, Studies in Byzantine Institutions. Society and Cultrure, Malibu 1997, s. 262; M.P. Ni11s o n, op. cit., s. $84 \mathrm{i} \mathrm{n.}$

${ }^{30}$ L. Ziehen, op. cit., s. 582.

${ }^{31}$ Theodretus Cyrensis, Graecarum affectione curatio VIII, 69, thum. S. Kalinkowski, [w:] Te od oret z Cyru, Leczenie chorób hellenizmu, Warszawa 1981 , s. $188-189$. 
męczenników, który w ich ocenie, ale też w opinii części autorów chrześcijańskich był nie do pogodzenia $z$ chrześcijaństwem.

Powracając do opisów nieprzyzwoitych zachowań chrześcijan przybyłych na uroczystość święta męczenników, przytoczmy jeszcze relację Hieronima ze Strydonu. W jednym ze swoich listów adresowanych do rzymskiej matrony Lety poucza on adresatkę, jak ma wychować córkę. Wśród wielu zaleceń podaje: „Pamiętajcie wy, rodzice, o dziewicy; pamiętajcie, że więcej można ją nauczyć przykładami niż słowami. Szybko marnieją kwiaty, zatrute powietrze zaś niszczy fiołki $[. .$.$] . Niech nigdy nie wychodzi bez ciebie na miejsce$ publiczne. Do bazylik męczenników i do kościołów niech nie chodzi bez matki. Niech się nie uśmiecha do niej żaden pięknie uczesany młodzieniec. W dni wigilijne i uroczyste noce czuwania niech nasza dziewczyna ani na szerokość paznokcia nie odstępuje od matki" ${ }^{32}$.

Hieronim, uważny obserwator otaczajacej go rzeczywistości oraz wielki autorytet moralny wśród chrystianizującej się arystokracji rzymskiej, znając atmosferę i okoliczności, w jakich tego typu święta przebiegały, raczej wiedział o czym pisze.

Jarmarki towarzyszące corocznym świętom ku czci bogów i herosów były więc ważnym elementem życia codziennego człowieka antyku. Od drugiej połowy IV w. coraz częściej towarzyszyły świętom ku czci męczenników, które podobnie jak święta pogańskie przyciagały liczne rzesze pątników, nie zawsze jednak przybywających tam tylko $z$ religijnych pobudek. Nie inaczej było również w przypadku świąt męczenników w epoce masowej chrystianizacji społeczeństwa rzymskiego. Masowość tego zjawiska skutkowała przede wszystkim jego powierzchownością, co wyrażało się m.in. w długo utrzymujących się różnorakich obyczajach pogańskich w życiu codziennym chrześcijan. Jednym $z$ takich zapożyczeń był opisany zwyczaj organizowania jarmarku w dniu święta męczennika. Co oczywiste, choć znane mi źródła nic o tym nie wspominają, organizowanie jarmarku przy okazji świąt męczenników musiało być również źródłem sporych dochodów dla lokalnych Kościołów czerpiących korzyści nie tylko $z$ faktu udostępnienia kupcom powierzchni handlowej, lecz też ze sprzedaży różnego rodzaju dewocjonaliów związanych $z$ kultem miejscowego świętego: krzyżyków - fylakterionów nowego typu, napełnionych „cudowną" wodą bądź oliwą buteleczek i ampułek opatrzonych wizerunkiem świętego męża, którego „odwiedzono”

${ }^{32}$ Hieronymus, Epistula CVII, 9, „Patrologia Latina” [Paris] 1862, t. XXI, col. 875; tłum. J. Czuj, [w:] Hie ro ni m, Listy, t. II, Warszawa 1953, s. 409. 
$\mathrm{w}$ martyrionie $\mathrm{w}$ dniu jego święta. Organizatorzy interesujących nas jarmarków musieli zapewne także zorganizować służby porządko$\mathrm{we}^{33}$. W zestawionych relacjach dostrzegamy ubolewanie późnoantycznych kaznodziejów chrześcijańskich nad niedostatecznym przeżywaniem przez wiernych uroczystości religijnych towarzyszących świętom męczenników. I zapewne narzekania te nie były pozbawione racji, dla wielu bowiem chrześcijan święto ku czci męczennika stwarzało przede wszystkim okazję do pohandlowania oraz wzięcia udziału w rozrywce, która gwarantował festyn ludowy stanowiący część zorganizowanego jarmarku. Pod tym względem więc nic się nie zmieniło i zmienić się nie mogło w stosunku do dawnej, antycznej tradycji.

\section{Bibliografia}

\section{Ź RÓDEA DRUKOWANE}

Basilius Magnus, In Gordium martyrem, „Patrologia Graeca” [Paris] 1857, t. XXXI. Basilius Magnus, In Mamantem homilia, „Patrologia Graeca” [Paris] 1857, t. XXXI. Basilius Magnus, Regulae fusius tractatus 40, „Patrologia Graeca” [Paris] 1857, t. XXXI; tłum. J. Naumowicz, [w:] Św. Bazyli Wielki, Pisma Ascetyczne, t. II, Kraków 1995, Źródła monastyczne, t. VI.

Basilius Seleuciensis, De vita Theclae, „Patrologia Graeca” [Paris] 1864, t. LXXXV. Dio Chrysostom, Orationes, [w:] idem, Discources 12-30, ed. J.W. Cohoon, Cambridge-London 1939.

Gregorius Nyssenus, De sancto Theodoro martyre, „Patrologia Graeca” [Paris] 1863, t. XLVI.

Gregorius Nyssenus, Oratio prima in quadraginta martyres, „Patrologia Graeca” [Paris] 1863, t. XLVI.

Hieronymus, Epistulae, „Patrologia Latina” [Paris] 1862, t. XXI; tłum. J. Czuj, [w:] Hieronim, Listy, t. II, Warszawa 1953.

Joannes Chrysostomus, De sancto Babyla, contra Julianum et gentiles, „Patrologia Graeca" [Paris] 1862, t. L.

Joannes Chrysostomus, De sanctis martyribus, „Patrologia Graeca” [Paris] 1866, t. XLIX.

Konstytucje Apostolskie, tłum. S. Kalinkowski, [w:] Konstytucje apostolskie oraz Kanony Pamfilosa $z$ apostolskiego synodu $w$ Antiochii, Prawo kanoniczne św. Apostołów, Kary świętych Apostołów dla upadłych, Euchologion Serapiona. [w:] Synody i kolekcje praw (= Synodi et Collectiones Legum), t. II, wyd. A. Baron, H. Pietras, Kraków 2007.

${ }^{33}$ L. Ziehen, op. cit., s. 582. 
Theodoretus Cyrensis, Graecarum affectione curratio, „Patrologia Graeca” [Paris] 1864, t. LXXXIII; tłum. S. Kalinkowski, [w:] Teodoret z Cyru, Leczenie chorób hellenizmu, Warszawa 1981.

Theodoretus Cyrensis, Historia religiosa, „Patrologia Graeca” [Paris] 1864, t. LXXXII; tłum. K. Augustyniak, [w:] Teodoret z Cyru, Dzieje miłości Bożej. Historia mnichów syryjskich, Kraków 1994, Źródła monastyczne, t. VII.

\section{Opracowania}

Bagnall R., Egypt in Late Antiquity, Princeton 1993.

Begon P.M., The Cappadocian Fathers, Women and Ecclesiastical Politics, „Vigiliae Christianae" 1995, vol XLIX, s. 165-179.

Bernardi J., La prédication des Pères Cappadociens, Montpellier 1968.

Engemann J., Palästinische frühchristliche Pilgerampullen. Erstveröffentlichungen und Berichtigungen, „Jahrbuch für Antike und Christentum” 2002, Jg. XLV, s. $153-169$.

Frankfurter D., Religion in Roman Egypt. Assimilation and Resistance, Princeton 1998.

Garrison J.D., Dryden and the Tradition of Panegryric, Berkeley-Los Angeles-London 1975.

Gasco F., Menander Rhetor and the Works Attributed to Him, [w:] „Aufstieg und Niedergang der Römischen Welt', Serie II, Bd. XXXIV, Tl. 4, Berlin-New York 1998, s. 3110-3146.

Girardi M., Basilio di Cesarea e il culto dei martyri nel IV secolo. Scrittura et tradizione, Bari 1990.

Graham M.W., News and Frontier Consciousness in the Late Roman Empire, Michigan 2009.

Grig L., Making Martyrs in Late Antiquity, London 2004.

Harl K., From Pagan to Christian in Cities of Roman Anatolia during the Fourth and Fifth Centuries, [w:] Urban Centers and Rural Contexts in Late Antiquity, eds Th.S. Burns, J.W. Eadie, East Lansing 2001.

Harland A., Travel and Religion in Antiquity, Waterloo 2011.

Hellenkamper H., Hild L., Lykien und Pamphylien, Wien 2004.

James E.O., Seasonal Feast and Festivals, New York 1961.

Karras V., Life of St. Elisabeth the Wonderworker, [w:] A.M. Talbot, Holy Women of Byzantium. Ten Saints'Lives in English Translation, Washington 2006, s. $117-138$.

Kaufmann C.M., Die heilige Stadt der Wüste, Kempten 1924.

Kennedy G., The Art of Persuasion in Greece, Princeton 1963.

Kötting B., Peregrinatio religiosa. Wallfahrten in der Antike und das Pilgerwesen in der alten Kirche, Münster 1980.

Leemans J., Individualization and the Cult of the Martyrs: Examples from Asia Minor in the Fourth Century, [w:] The Individual in the Religions of the Ancient Mediterranean, ed. J. Rüpke, Oxford 2013, s. 187-214. 
Leipoldt J., Schenute von Atripe und die Entstehung des national - ägyptischen Christentum, Leipzig 1903.

Light de L., Fairs and Markets in the Roman Empire. Economic and Social Aspects of Periodic Trade in a Pre-Industrial Society, Amsterdam 1993.

Ligt de L., Neeve de P.W., Ancient Periodic Markets. Festivals and Fairs, „Athanaeum" 1988, vol. LXXV, s. 391-416.

Litsas F.K., Choricius of Gaza and his Description of Festivals at Gaza, „Jahrbuch der Österreichischen Byzantinistik" 1982, Jg. XXXII, s. 427-436.

Menirav J., Rosenfeld B.Z., Markets and Marketing in Roman Palestine, Leiden 2005.

Milewski I., Kilka uwag o paramedycznym zastosowaniu oliwy przez chrześcijan w okresie wczesnobizantyńskim, „Vox Patrum” 2014, R. LXII, s. 357-364.

Morley N., The Market in Classical Antiquity, [w:] M. Frass, Kauf und Märkte. Wirtschaftsleben im Focus. Vom der römischen Antike bis zur Gegenwart, Wiesbaden 2013, s. 103-122.

Nijf van O.M., The Civic World of Professional Associations in the Roman East, Leiden 1997.

Nillson M.P., Greek Folk Religion, New York 1998.

Orselli A.M., L'idée chrétienne de la ville: quelques suggestions pour l'Antiquité Tardive et le haut Moyen Age, [w:] The Idea and Ideal of the Town between Late Antiquity and the Early Middle Ages, eds G.P. Brogiolo, B. Ward-Perkins, Leiden-Boston-Köln 1999, s. 181-194.

Papaconstantinou A., The Cult of Saints: A Haven of Continuity in a Changing World, [w:] Egypt in the Byzantine World, 300-700, ed. R.S. Bagnall, Cambridge 2007.

Price S.R.F., Rituals and Power. The Roman Imperial Cult in Asia Minor, Cambridge 2002.

Speck F., Handelsgeschichte des Altertums, Bd. II (Die Griechen), Paderborn 1901.

Vikan G., "Guided by Land and Sea”. Pilgrim Art and Pilgrim Travel in Early Byzantium', [w:] Tesserae: Festschrift für Josef Engemann, „Jahrbuch für Antike und Christentum. Ergänzungsband" 1991, Jg. XVIII, s. 79-81.

Vryonis S., Studies in Byzantine Institutions, Society and Cultrure, Malibu 1997.

Vryonis S., The Panegyris of the Byzantine Saint. A Study in the Nature of a Medieval Institution, its Origin and Fate, [w:] The Byzantine Saint, ed. S. Hackel, London 1981, s. 196-226.

Ziehen L., Panegyris, „Real - Encyclopädie der classischen Altertumswissenschaften” 1983, Jg. XVIII, T1. 3, s. 581-583. 